CENDEKIA, Vol. 9, No. 2, Oktober 2015

p ISSN: 1978 2098; e ISSN: 2407 8557; Web: cendekia.pusatbahasa.or.id Pusat Kajian Bahasa dan Budaya, Surakarta, Indonesia

Zaitun, Siti. 2015. Pengaruh Layanan Bimbingan Penyuluhan terhadap Kenakalan Anak Kelas VI SDN 005 Bontang Utara. Cendekia, 9(2): 195 206.

\title{
PENGARUH LAYANAN BIMBINGAN PENYULUHAN TERHADAP KENAKALAN ANAK KELAS VI SDN 005 BONTANG UTARA
}

\author{
Siti Zaitun \\ Guru SDN 005 Bontang Utara
}

\begin{abstract}
This study was intended to see the relationship between counseling guidance and juvenile delinguency. The subject of this study was 63 students of the sixth grade of SDN 005 Bontang Utara. This study used questionnaire consiting of 10 items to identify main data on the effectiveness of counceling guidance and juvenile delinguency. In addition, documentary analysis regarding the counceling and juvenile delinguency was used complimentary to the questionnaire. The analysis of the data discovered three descriptions: counceling guidance, juvenile delinguency, and the relationship between counceling guidance and juvenile delinguency. Results of guidance counceling indicated that of 63 respondents, $33 \%$ or 21 received good services, $38 \%$ or 24 enough, and $29 \%$ or 18 low. The juvenile delinguency indicated that of 63 respondents, $50 \%$ or 31 respondents performed low traits, $25 \%$ or 16 enough, and $25 \%$ or 16 high. The hypothesis testing indicated that $r$-value $(0.850)$ was greater than $\mathrm{r}$-table $(0.244)$ at $\mathrm{p}=0.05, \mathrm{~N}=63$. The result is significant, meaning the better the quality of guidance counceling, the lower the juvenile deinguency was performed by the respondents.
\end{abstract}

Keywords: guidance counceling, juvenile delingeuncy.

DALAM menghadapi anak, ada beberapa hal yang harus selalu diingat bahwa jiwa anak adalah jiwa yang penuh gejolak, dan bahwa lingkungan sosial anak juga ditandai dengan perubahan sosial yang cepat (khususnya di kota-kota besar dan daerah yang sudah terjangkau sarana dan prasarana komunikasi dan perhubungan) yang mengakibatkan kesimpangsiuran norma (keadaan naomi). Kondisi intern dan ekstern yang yang sama-sama bergejolak inilah yang mengakibatkan masa anak memang lebih rawan daripada tahap-tahap lain dalam perkembangan jiwa manusia (Sarwono, 1988:219).

Generasi muda telah kehilangan pegangan dan keteladanan para orang tua. Generasi muda juga kehilangan figur orang tua yang bisa digugu dan ditiru, sehingga generasi muda cenderung bertingkah laku yang dapat merugikan dirinya sendiri dan kebutaan etika. Untuk membenahi tatanan yang sudah tidak tertata itu, bangsa ini membutuhkan para konselor yang profesional yang bisa menciptakan dan memulihkan kembali kepercayaan terhadap publik.

Bimbingan dan Penyuluhan (BP) sebagai salah satu unsur pendidikan, memegang peranan yang sangat penting karena bersentuhan secara langsung dengan aspek pribadi siswa. Dengan kata lain, BP merupakan proses intervensi yang bersifat 
CENDEKIA, Vol. 9, No. 2, Oktober 2015

p ISSN: 1978 2098; e ISSN: 2407 8557; Web: cendekia.pusatbahasa.or.id

Pusat Kajian Bahasa dan Budaya, Surakarta, Indonesia

Zaitun, Siti. 2015. Pengaruh Layanan Bimbingan Penyuluhan terhadap Kenakalan Anak Kelas VI SDN 005 Bontang Utara. Cendekia, 9(2): 195 206.

membantu individu mengubah perilaku dan pencapaian perkembangan pribadi secara optimal.

Tugas pelaksana BP di sekolah adalah menciptakan lingkungan belajar sebagai lingkungan terstruktur yang sengaja dirancang untuk memberikan peluang kepada siswa dalam mempelajari perilaku baru, meningkatkan prestasi dan persepsi sejalan dengan kebutuhan dan motif dasar siswa itu sendiri karena proses BP menyangkut proses perilaku manusia yang terwujud dalam perubahan perilaku.

Pada sisi lain, kinerja guru BP sendiri dinilai masih rendah yang menunjukkan kurang profesionalnya guru BP itu sendiri. Hal tersebut disebabkan tidak terlaksananya pendidikan maupun pelatihan bagi guru BP dalam menunjang pekerjaannya agar mampu secara nyata melaksanakan kegiatan menurut kaidah-kaidah keilmuan, teknologi, dan kode etik profesionalme tugas yang diembannya..

Di lain pihak, dukungan, kerja sama, dan saling pengertian di antara pihak yang terkait, belum berjalan secara optimal. Kurang terwujudnya saling pengertian, kerja sama, dan saling mendukung di antara personil sekolah, menyebabkan guru BP tidak mampu memberikan layanannya secara maksimal, sehingga layanan BP tidak dapat dirasakan manfaatnya secara optimal oleh semua pihak yang terkait khususnya para siswa yang menginjak usia anak, sehingga dapat menimbulkan kenakalan pada anak.

Dewasa ini, perkembangan BP menjadi amat relevan diterapkan dalam konteks sosio-kultural masyarakat Indonesia yang sedang mengalami berbagai krisis. Profesi BP menjadi sangat penting peranannya dalam dunia pendidikan. Mengingat dalam era globalisasi di segala bidang, terjadi berbagai perubahan mendasar yang mengguncang dunia sosial kemasyarakatan.

Beberapa sebab yang mengakibatkan kehidupan anak-anak dan para anak tak terarah sehingga menimbulkan apa yang disebut dengan kenakalan anak, di antaranya ialah: kurangnya perhatian dari orang tua maupun guru, kurangnya wahana bermain, langkanya sarana rekreasi yang sehat, dan banyaknya waktu senggang, serta tidak efektifnya layanan BP di sekolah.

Pasal 27 Peraturan Pemerintah Nomor 29/90 menyebutkan bahwa, "Bimbingan merupakan bantuan yang diberikan kepada siswa dalam rangka upaya menemukan pribadi, mengenal lingkungan, dan merencanakan masa depan" (Depdikbud dalam Sukardi, 2000:18). Sedangkan Prayitno (1999:94) mengungkapkan bimbingan sebagai proses layanan yang diberikan kepada individu guna membantu mereka memperoleh pengetahuan dan keterampilan yang diperlukan dalam membuat pilihan, rencana, dan interpretasi yang diperlukan untuk menyesuaikan diri yang baik. Penyuluhan adalah kegiatan dimana semua fakta dikumpulkan dan semua pengalaman siswa difokuskan pada masalah tertentu untuk diatasi sendiri oleh yang bersangkutan, dimana ia diberi bantuan pribadi dan langsung dalam pemecahan masalah itu. Konselor tidak memecahkan masalah untuk klien. Penyuluhan harus ditujukan pada perkembangan yang progresif dari individu untuk memecahkan masalahnya sendiri tanpa bantuan.

Sesuai dengan pengertian BP sebagai suatu upaya membentuk perkembangan kepribadian siswa secara optimal, secara umum layanan BP di sekolah, haruslah dikaitkan dengan pengembangan sumber daya manusianya. Secara khusus layanan bertujuan untuk membantu siswa agar dapat mencapai tujuan perkembangan meliputi aspek pribadi-sosial, belajar, dan karir (Sukardi, 2000:29). 
CENDEKIA, Vol. 9, No. 2, Oktober 2015

p ISSN: 1978 2098; e ISSN: 2407 8557; Web: cendekia.pusatbahasa.or.id

Pusat Kajian Bahasa dan Budaya, Surakarta, Indonesia

Zaitun, Siti. 2015. Pengaruh Layanan Bimbingan Penyuluhan terhadap Kenakalan Anak Kelas VI SDN 005 Bontang Utara. Cendekia, 9(2): 195 206.

Dengan demikian, BP di sekolah bertujuan untuk membantu siswa dalam: (a) menemukan diri agar siswa mengenal kekuatan dan kelemahan diri sendiri, (b) mengenal lingkungan agar siswa mengenal secara objektif lingkungan, baik lingkungan sosial dan ekonomi, lingkungan budaya yang sarat dengan nilai dan norma-norma, maupun lingkungan fisik, dan menerima berbagai kondisi lingkungan itu secara positif dan dinamis, dan (c) merencanakan masa depanagar siswa mampu mempertimbangkan dan mengambil keputusan tentang masa depan dirinya sendiri, baik yang menyangkut bidang pendidikan, karir, maupun budaya/kemasyarakatan.

Ditinjau dari sifatnya, layanan BP menurut Sukardi (2000:26-27), dapat dikelompokkan ke dalam fungsi pencegahan, fungsi pemahaman, fungsi perbaikan, dan fungsi pemeliharaan dan pengembangan.

Fungsi pencegahan maksudnya merupakan usaha pencegahan terhadap timbulnya masalah dengan layanan berupa bantuan bagi para siswa agar terhindar dari berbagai masalah yang dapat menghambat perkembangannya melalui kegiatan berupa; program orientasi, program bimbingan karir, dan inventarisasi data.

Fungsi ini merupakan fungsi BP yang akan menghasilkan pemahaman tentang sesuatu oleh pihak-pihak tertentu sesuai keperluan pengembangan siswa, yang meliputi: pemahaman tentang diri siswa, pemahaman tentang lingkungan siswa, dan pemahaman tentang lingkungan yang lebih luas seperti; pendidikan, pekerjaan, jabatan, dan budaya. Namun demikian, pemahaman yang sangat perlu dihasilkan oleh pelayanan BP adalah pemahaman tentang diri klien (siswa) beserta permasalahannya oleh klien sendiri dan oleh pihak-pihak yang akan membantu klien, serta pemahaman tentang lingkungan klien oleh klien (Prayitno, 1999:197).

Merupakan fungsi BP yang akan menghasilkan terpecahkannya atau teratasinya berbagai permasalahan yang dialami siswa. Fungsi ini tetap berperan dalam kegiatan BP karena adanya kemungkinan siswa masih menghadapi masalah-masalah tertentu walaupun fungsi pencegahan dan pemahaman sudah dilakukan. Dengan maksud yang sama, Prayitno (1999:209) menyebut fungsi ini dengan istilah fungsi pengentasan dimana orang yang mengalami masalah itu dianggap berada dalam suatu keadaan yang tidak mengenakkan sehingga perlu diangkat atau dikeluarkan dari bendanya yang tidak mengenakkan melalui pelayanan BP.

Fungsi ini berarti bahwa layanan BP yang diberikan, dapat membantu para siswa dalam memelihara dan membangkitkan keseluruhan pribadinya secara mantap, terarah, dan berkelanjutan. Dengan demikian, siswa dapat memelihara dan mengembangkan potensi potensi dan kondisi yang positif dalam pengembangan dirinya secara optimal. Dalam pelayanan BP, fungsi ini dapat dilakukan melalui berbagai pengaturan, kegiatan, dan program, misalnya; penyesuaian ukuran meja kursi dengan bentuk tubuh siswa, pengaturan ventilasi, suhu, bentuk, dan susunan ruang kelas agar dapat menimbulkan rasa nyaman dalam melakukan aktivitasnya.

Masa anak merupakan masa dimana terjadi proses peralihan dari masa anakanak ke masa dewasa dan terjadi proses penyempurnaan perkembangan, baik pada aspek fisik, psikis, dan sosial dengan ciri-ciri tertentu. Gunarso (1981:82) mengemukakan tentang ciri-ciri anak antara lain: (1) kegelisahan; keadaan yang tidak tenang menguasai diri si anak, (2) pertentangan; pertentangan-pertentangan yang terjadi di dalam diri mereka juga menimbilkan kebingungan, baik bagi diri mereka sendiri 
CENDEKIA, Vol. 9, No. 2, Oktober 2015

p ISSN: 1978 2098; e ISSN: 2407 8557; Web: cendekia.pusatbahasa.or.id

Pusat Kajian Bahasa dan Budaya, Surakarta, Indonesia

Zaitun, Siti. 2015. Pengaruh Layanan Bimbingan Penyuluhan terhadap Kenakalan Anak Kelas VI SDN 005 Bontang Utara. Cendekia, 9(2): 195 206.

maupun orang lain, (3) berkeinginan besar mencoba segala hal yang belum diketahui, (4) keinginan mencoba sering kali diarahkan pada diri sendiri maupun orang lain, (5) keinginan menjelajah ke alam sekitar pada anak, lebih luas, (6) mengkhayal dan berfantasi, dan (7) aktivitas berkelompok.

Dengan melihat ciri-ciri dari anak tersebut, maka dapat disimpulkan bahwa pada masa anak terjadi perubahan dalam pertumbuhan fisik, psikis, maupun sosial. Oleh karena itu orang tua perlu memperhatikan perubahan-perubahan yang terjadi pada anak, sehingga dapat memberikan pengertian dan petunjuk yang tepat mengenai perubahan tersebut agar anak dapat tumbuh dan berkembang secara wajar dan positif.

Untuk menetapkan sebab musabab kenakalan anak, adalah merupakan hal yang sulit, karena mesti memperhitungkan faktor-faktor pribadi anak, pengaruh sosial, dan pengaruh lainnya seperti riwayat hidup anak yang bersangkutan sejak kecil. Faktor keluarga juga penting dipertimbangkan sebagai faktor penyebab kenakalananak karena keluarga merupakan lingkungan pertama,dan lingkungan primer dimana anak sering melakukan interaksi sosial dalam pengembangan jati dirinya.

Pada garis besarnya, faktor penyebab kenakalan anak dapat dibedakan menjadi dua, yaitu faktor intern dan faktor ekstern. Faktor yang berpangkal pada diri anak sendiri disebut dengan faktor intern, sedangkan faktor yang berpangkal pada lingkungannya disebut faktor ekstern. Dalam hal ini. Gunarso (1981:34) menjelaskan ada dua kemungkinan sebab-sebab kenakalan anak. Pertama, kemungkinan berpangkal pada diri anak sendiri, yang meliputi: kekurangan penampungan emosional, kelemahan dalam mengendalikan dorongan dan kecenderungannya, kegagalan prestasi sekolah atau pergaulan, dan kekurangan dalam pembentukan hati nurani. Kedua, kemungkinan berpangkal pada lingkungan, meliputi: lingkungan keluarga dan lingkungan masyarakat, meliputi: perkembangan teknologi, faktor sosial, politik, sosial ekonomi dengan mobilitas, dan kepadatan penduduk.

Sejalan dengan pendapat di atas, Simanjuntak (1984:122) menyebutkan factor internal dan faktor eksternal merupakan penyebab kenakalan anak. Faktor intern terdiri dari (1) personality (kepribadian), meliputi: bio fisik, IQ, dan umur, (2) jenis kelamin, dan (3) kedudukan dalam keluarga. Faktor eksternal terdiri dari: (1) lingkungan keluarga, meliputi: disharmoni keluarga dan broken home, sikap perlindungan yang berlebihan, dan pendidikan anak terlantar, dan (2) lingkungan sosio-budaya, meliputi: lingkungan sekolah, media komunikasi masa, dan konflik kebudayaan.

\section{METODE}

Penelitian ini menggunakan pendekatan kuantitatif dengan rancangan deskriptif korelasional. Penelitian tentang layanan BP dan kenakalan anak ini mengambil tempat penelitian di SDN 005 Bontang Utara. Penelitian dilaksanakan terhadap siswa kelas VI pada semester genap selama kurang lebih enam bulan. Jumlah populasi sebanyak 63 orang dan peneliti mengambil semuanya sebagai sampel.

Pengumpulan data dalam penelitian ini digunakan metode angket, yaitu sejumlah pertanyaan tertulis yang digunakan untuk memperoleh informasi dari responden dalam arti laporan tentang pribadinya, atau hal-hal yang ia ketahui. Jenis angket yang digunakan dalam penelitian ini adalah angket tertutup, yaitu angket yang menghendaki jawaban pendek dan tertentu yang disediakan oleh peneliti. Sedangkan 
sebagai data pelengkap ialah dokumentasi, berupa catatan tentang kenakalan anak dari guru BP atau dari wali kelas untuk melengkapi data tentang layanan BP dan kenakalan anak yang dirasa masih kurang karena tidak terisi atau tidak terjawab.

Hasil jawaban dari kuesioner, selanjutnya diklasifikasikan berdasarkan katagori baik, cukup, dan kurang. Sedangkan data kenakalan anak digolongkan menjadi tiga katagori, yaitu: kurang, cukup, dan nakal. Untuk mengetahui masing-masing katagori tiap variabel, dapat digunakan rumus interval dari Sudjana (1984:46) sebagai berikut:

$$
\text { p = }
$$

Keterangan:

$\mathrm{p} \quad=$ interval

Skor ideal = jumlah skor tertinggi yang dicapai siswa

Skor terendah $=$ jumlah skor terendah yang dicapai siswa

Jenjang skala $=$ jumlah kelas atau katagori

Sedangkan untuk mengetahui distribusi masing-masing katagori tiap variabel, digunakan rumus persentase menurut Budiono (2003:40) sebagai berikut:

$$
P=\frac{F}{N} x 100 \%
$$

Keterangan:

$$
\begin{array}{ll}
\mathrm{P} & =\text { persentase } \\
\mathrm{F} & =\text { frekuensi dalam katagori } \\
\mathrm{N} & =\text { jumlah sampel/responden }
\end{array}
$$

Untuk mengetahui signifikansi pengaruh layanan BP terhadap kenakalan anak digunakan analisis korelasi product moment. Rumus yang digunakan adalah sebagai berikut (Sulaiman, 1996:254):

$$
r_{x y}=\frac{\sum x y}{\sqrt{\left(\sum x^{2}\right)\left(\sum y^{2}\right)}}
$$

Keterangan:

$\mathrm{r}_{\mathrm{XY}}=$ Korelasi antara variabel $\mathrm{X}$ dengan variabel $\mathrm{Y}$

$\sum x y=$ Jumlah skor $\mathrm{x}$ dikalikan skor $\mathrm{y}$

$\sum x^{2}=$ Jumlah skor $\mathrm{x}$ yang dikuadratkan

$\sum y^{2}=$ Jumlah skor y yang dikuadratkan

Dari hasil analisis selanjutnya dapat diinterpretasi untuk mengetahui keeratan hubungan berdasarkan kriteria dari Arikunto (1996:258) sebagai berikut:

Tabel 1. Interpretasi Korelasi

\begin{tabular}{|l|l|l|} 
No & Besarnya Nilai R & Interpretasi \\
\hline
\end{tabular}


CENDEKIA, Vol. 9, No. 2, Oktober 2015

p ISSN: 1978 2098; e ISSN: 2407 8557; Web: cendekia.pusatbahasa.or.id Pusat Kajian Bahasa dan Budaya, Surakarta, Indonesia

Zaitun, Siti. 2015. Pengaruh Layanan Bimbingan Penyuluhan terhadap Kenakalan Anak Kelas VI SDN 005 Bontang Utara. Cendekia, 9(2): 195 206.

\begin{tabular}{|c|c|c|}
\hline 1 & 0,80 sampai 1,00 & Tinggi \\
\hline 2 & 0,60 sampai 0.80 & Cukup \\
\hline 3 & 0,40 sampai 0,60 & Agak rendah \\
\hline 4 & 0,20 sampai 0,40 & Rendah \\
\hline 5 & 0,00 sampai 0,20 & Sangat rendah \\
\hline
\end{tabular}

\section{HASIL DAN BAHASAN}

Bagian ini menguraikan mengenai analisis dan pembahasan. Data dalam analisis disajikan ke dalam tiga katagori: layanan BP, kenakalan anak, dan uji hipotesis.

\section{Layanan BP}

Data layanan BP diungkap dengan menggunakan metode angket atau kuesioner dengan jumlah item sebanyak 10 pertanyaan, dimana dalam setiap pertanyaan di disediakan tiga alternatif pilihan jawaban. Kemudian tiap-tiap jawaban diberi skor, skor tertinggi diberi nilai 3 dan skor terendah diberi nilai 1.

Hasil angket menunjukkan bahwa dari 63 siswa, diperoleh skor tertinggi sebesar 30 , skor terendah sebesar 16 , dan total skor sebesar 1461. Sedangkan rata-rata skor angket diperoleh sebesar 23,2.

Hasil penghitungan tersebut menunjukkan bahwa besarnya interval untuk masing-masing katagori layanan BP yang ditetapkan sebesar 4,7. Jadi, katagori layanan BP dapat ditentukan sebagai berikut:

a. Katagori baik, skor antara 25,5 sampai 30,0

b. Katagori cukup, skor antara 20,8 sampai 25,4

c. Katagori kurang, skor antara 16,0 sampai 20,7

Dengan demikian, skor hasil pengisian angket layanan BP dapat dikelompokkan berdasarkan masing-masing katagori seperti termuat dalam tabel di bawah ini.

Tabel 2. Katagori Layanan BP

\begin{tabular}{|c|l|c|c|}
\hline Nomor & \multicolumn{1}{|c|}{ Katagori } & Jumlah & Persentase \\
\hline 1 & Baik & 21 & $33 \%$ \\
\hline 2 & Cukup & 24 & $38 \%$ \\
\hline 3 & Kurang & 18 & $29 \%$ \\
\hline & Total & 63 & $100 \%$ \\
\hline
\end{tabular}

Sumber Data: Hasil Kuesioner

Dari tabel di atas dapat dijelaskan bahwa layanan BP terhadap 63 siswa kelas VI SDN 005 Bontang Utara, sebanyak 33\% atau 21 siswa mendapatkan layanan BP katagori baik, sebanyak $38 \%$ atau 24 siswa mendapatkan layanan katagori cukup, dan $29 \%$ atau 18 siswa yang mendapat layanan BP pada katagori kurang. Rata-rata skor layanan BP sebesar 23,2. Skor tersebut jika dikatagorikan ke dalam kriteria yang telah ditentukan sebelumnya, termasuk dalam layanan BP katagori cukup.

\section{Kenakalan Anak}


Data tentang kenakalan anak dalam penelitian ini diperoleh dengan menggunakan metode angket dengan jumlah item sebanyak 10 pertanyaan dan setiap pertanyaan disediakan tiga alternatif jawaban. Tiap-tiap jawaban diberi skor, skor tertinggi diberi nilai 3 dan skor terendah diberi nilai 1.

Hasil jawaban angket siswa mengenai kenakalan anak dari 63 siswa kelas VI SDN 005 Bontang Utara diperoleh skor tertinggi sebesar 30, skor terendah sebesar 18, dan total skor jawaban angket sebesar 1590. Sedangkan rata-rata skor angket siswa sebesar 25,2. Dari hasil penghitungan di atas menunjukkan bahwa besarnya interval untuk masing-masing katagori kenakalan anak adalah 4. Dengan demikian, katagori kenakalan anak dapat ditentukan sebagai berikut:

a. Katagori kurang, skor antara 27 sampai 30

b. Katagori cukup, skor antara 23 sampai 26

c. Katagori nakal, skor antara 18 sampai 22.

Dengan demikian, dari hasil penghitungan di atas selanjutnya skor masingmasing katagori kenakalan anak pada siswa kelas VI SDN 005 Bontang Utara dapat dikelompokkan berdasarkan persentase pada masing-masing katagori sebagaimana termuat dalam tabel 3 di bawah ini:

Tabel 3. Katagori Kenakalan Anak

\begin{tabular}{|c|l|c|c|}
\hline Nomor & \multicolumn{1}{|c|}{ Katagori } & Jumlah & Persentase \\
\hline 1 & Kurang & 31 & $50 \%$ \\
\hline 2 & Cukup & 16 & $25 \%$ \\
\hline 3 & Nakal & 16 & $25 \%$ \\
\hline & Total & 63 & $100 \%$ \\
\hline
\end{tabular}

Sumber: Kuesioner

Berdasarkan tabel di atas dapat dijelaskan bahwa kenakalan anak dari 63 siswa kelas VI SDN 005 Bontang Utara, diperoleh sebanyak 50\% atau 31 siswa mengalami kenakalan katagori kurang, 25\% atau 16 siswa mengalami kenakalan katagori cukup, dan $25 \%$ atau 16 siswa lainnya mengalami kenakalan katagori nakal. Sedangkan ratarata skor kenakalan anak adalah 25,2 dan jika dikatagorikan ke dalam kriteria yang telah ditentukan, termasuk dalam kenakalan anak katagori cukup.

\section{Hubungan Antara Layanan BP dengan Kenalakan Anak}

Untuk mencari hubungan antara variabel layanan BP (X) dengan kenakalan anak (Y), terlebih dahulu dilakukan penghitungan dengan menggunakan tabel persiapan kerja untuk menghitung besarnya korelasi kedua variabel. Tabel kerja tersebut dimaksudkan untuk mempermudah dalam mencari dan menetapkan besarnya koefisien korelasi. Adapun metode yang digunakan untuk menghitung hubungan kedua variabel tersebut adalah rumus korelasi Product Moment Pearson.

Tabel 4. Tabel Persiapan Penghitungan Korelasi Product Moment

\begin{tabular}{|c|c|c|c|c|c|c|c|}
\hline No & $\mathbf{X}$ & $\mathbf{Y}$ & $\mathbf{X}$ & $\mathbf{Y}$ & $\mathbf{X y}$ & $x^{2}$ & $\mathbf{y}^{2}$ \\
\hline 1 & 22 & 23 & -1.19 & -2.24 & 2.67 & 1.42 & 5.02 \\
\hline
\end{tabular}


CENDEKIA, Vol. 9, No. 2, Oktober 2015

p ISSN: 1978 2098; e ISSN: 2407 8557; Web: cendekia.pusatbahasa.or.id Pusat Kajian Bahasa dan Budaya, Surakarta, Indonesia

Zaitun, Siti. 2015. Pengaruh Layanan Bimbingan Penyuluhan terhadap Kenakalan Anak Kelas VI SDN 005 Bontang Utara. Cendekia, 9(2): 195 206.

\begin{tabular}{|c|c|c|c|c|c|c|c|}
\hline 2 & 26 & 27 & 2.81 & 1.76 & 4.95 & 7.90 & 3.10 \\
\hline 3 & 27 & 30 & 3.81 & 4.76 & 18.14 & 14.52 & 22.66 \\
\hline 4 & 23 & 28 & -0.19 & 2.76 & -0.52 & 0.04 & 7.62 \\
\hline 5 & 28 & 29 & 4.81 & 3.76 & 18.09 & 23.14 & 14.14 \\
\hline 6 & 25 & 30 & 1.81 & 4.76 & 8.62 & 3.28 & 22.66 \\
\hline 7 & 30 & 28 & 6.81 & 2.76 & 18.80 & 46.38 & 7.62 \\
\hline 8 & 28 & 30 & 4.81 & 4.76 & 22.90 & 23.14 & 22.66 \\
\hline 9 & 24 & 20 & 0.81 & -5.24 & -4.24 & 0.66 & 27.46 \\
\hline 10 & 20 & 21 & -3.19 & -4.24 & 13.53 & 10.18 & 17.98 \\
\hline 11 & 21 & 25 & -2.19 & -0.24 & 0.53 & 4.80 & 0.06 \\
\hline 12 & 22 & 23 & -1.19 & -2.24 & 2.67 & 1.42 & 5.02 \\
\hline 13 & 26 & 27 & 2.81 & 1.76 & 4.95 & 7.90 & 3.10 \\
\hline 14 & 27 & 30 & 3.81 & 4.76 & 18.14 & 14.52 & 22.66 \\
\hline 15 & 23 & 28 & -0.19 & 2.76 & -0.52 & 0.04 & 7.62 \\
\hline 16 & 28 & 29 & 4.81 & 3.76 & 18.09 & 23.14 & 14.14 \\
\hline 17 & 24 & 20 & 0.81 & -5.24 & -4.24 & 0.66 & 27.46 \\
\hline 18 & 20 & 21 & -3.19 & -4.24 & 13.53 & 10.18 & 17.98 \\
\hline 19 & 16 & 18 & -7.19 & -7.24 & 52.06 & 51.70 & 52.42 \\
\hline 20 & 27 & 30 & 3.81 & 4.76 & 18.14 & 14.52 & 22.66 \\
\hline 21 & 23 & 27 & -0.19 & 1.76 & -0.33 & 0.04 & 3.10 \\
\hline 22 & 17 & 24 & -6.19 & -1.24 & 7.68 & 38.32 & 1.54 \\
\hline 23 & 27 & 30 & 3.81 & 4.76 & 18.14 & 14.52 & 22.66 \\
\hline 24 & 30 & 28 & 6.81 & 2.76 & 18.80 & 46.38 & 7.62 \\
\hline 25 & 25 & 24 & 1.81 & -1.24 & -2.24 & 3.28 & 1.54 \\
\hline 26 & 24 & 28 & 0.81 & 2.76 & 2.24 & 0.66 & 7.62 \\
\hline 27 & 17 & 21 & -6.19 & -4.24 & 26.25 & 38.32 & 17.98 \\
\hline 28 & 18 & 18 & -5.19 & -7.24 & 37.58 & 26.94 & 52.42 \\
\hline 29 & 20 & 23 & -3.19 & -2.24 & 7.15 & 10.18 & 5.02 \\
\hline 30 & 21 & 27 & -2.19 & 1.76 & -3.85 & 4.80 & 3.10 \\
\hline 31 & 26 & 28 & 2.81 & 2.76 & 7.76 & 7.90 & 7.62 \\
\hline 32 & 23 & 24 & -0.19 & -1.24 & 0.24 & 0.04 & 1.54 \\
\hline 33 & 16 & 20 & -7.19 & -5.24 & 37.68 & 51.70 & 27.46 \\
\hline 34 & 23 & 26 & -0.19 & 0.76 & -0.14 & 0.04 & 0.58 \\
\hline 35 & 27 & 30 & 3.81 & 4.76 & 18.14 & 14.52 & 22.66 \\
\hline 36 & 23 & 28 & -0.19 & 2.76 & -0.52 & 0.04 & 7.62 \\
\hline 37 & 28 & 24 & 4.81 & -1.24 & -5.96 & 23.14 & 1.54 \\
\hline 38 & 19 & 20 & -4.19 & -5.24 & 21.96 & 17.56 & 27.46 \\
\hline 39 & 20 & 23 & -3.19 & -2.24 & 7.15 & 10.18 & 5.02 \\
\hline 40 & 21 & 21 & -2.19 & -4.24 & 9.29 & 4.80 & 17.98 \\
\hline 41 & 20 & 23 & -3.19 & -2.24 & 7.15 & 10.18 & 5.02 \\
\hline 42 & 22 & 27 & -1.19 & 1.76 & -2.09 & 1.42 & 3.10 \\
\hline 43 & 18 & 22 & -5.19 & -3.24 & 16.82 & 26.94 & 10.50 \\
\hline 44 & 20 & 23 & -3.19 & -2.24 & 7.15 & 10.18 & 5.02 \\
\hline 45 & 19 & 22 & -4.19 & -3.24 & 13.58 & 17.56 & 10.50 \\
\hline
\end{tabular}


CENDEKIA, Vol. 9, No. 2, Oktober 2015

p ISSN: 1978 2098; e ISSN: 2407 8557; Web: cendekia.pusatbahasa.or.id Pusat Kajian Bahasa dan Budaya, Surakarta, Indonesia

Zaitun, Siti. 2015. Pengaruh Layanan Bimbingan Penyuluhan terhadap Kenakalan Anak Kelas VI SDN 005 Bontang Utara. Cendekia, 9(2): 195 206.

\begin{tabular}{|r|r|r|r|r|r|r|r|}
\hline 46 & 25 & 30 & 1.81 & 4.76 & 8.62 & 3.28 & 22.66 \\
\hline 47 & 30 & 28 & 6.81 & 2.76 & 18.80 & 46.38 & 7.62 \\
\hline 48 & 28 & 30 & 4.81 & 4.76 & 22.90 & 23.14 & 22.66 \\
\hline 49 & 24 & 26 & 0.81 & 0.76 & 0.62 & 0.66 & 0.58 \\
\hline 50 & 19 & 21 & -4.19 & -4.24 & 17.77 & 17.56 & 17.98 \\
\hline 51 & 21 & 18 & -2.19 & -7.24 & 15.86 & 4.80 & 52.42 \\
\hline 52 & 22 & 23 & -1.19 & -2.24 & 2.67 & 1.42 & 5.02 \\
\hline 53 & 26 & 27 & 2.81 & 1.76 & 4.95 & 7.90 & 3.10 \\
\hline 54 & 27 & 30 & 3.81 & 4.76 & 18.14 & 14.52 & 22.66 \\
\hline 55 & 23 & 26 & -0.19 & 0.76 & -0.14 & 0.04 & 0.58 \\
\hline 56 & 28 & 29 & 4.81 & 3.76 & 18.09 & 23.14 & 14.14 \\
\hline 57 & 24 & 27 & 0.81 & 1.76 & 1.43 & 0.66 & 3.10 \\
\hline 58 & 20 & 21 & -3.19 & -4.24 & 13.53 & 10.18 & 17.98 \\
\hline 59 & 16 & 18 & -7.19 & -7.24 & 52.06 & 51.70 & 52.42 \\
\hline 60 & 27 & 30 & 3.81 & 4.76 & 18.14 & 14.52 & 22.66 \\
\hline 61 & 23 & 27 & -0.19 & 1.76 & -0.33 & 0.04 & 3.10 \\
\hline 62 & 17 & 21 & -6.19 & -4.24 & 26.25 & 38.32 & 17.98 \\
\hline 63 & 27 & 30 & 3.81 & 4.76 & 18.14 & 14.52 & 22.66 \\
\hline Jumlah & 1461 & 1590 & & & 733 & 912 & 909 \\
\hline Sumber
\end{tabular}

Sumber Data: Pengolahan Jawaban Kuesioner

Berdasarkan pada tabel kerja tersebut di atas, dapat diketahui skor dan deviasi kedua variabel sebagai berikut:

$\sum x y=733$
$\sum x^{2}=912$
$\sum y^{2}=909$

Kemudian hasil penghitungan tersebut dianalisis dengan menggunakan rumus korelasi Product Moment untuk menghitung adanya hubungan kedua variabel, sebagai berikut:

$$
\begin{aligned}
r_{x y} & =\frac{\sum x y}{\sqrt{\left(\sum x^{2}\right)\left(\sum y^{2}\right)}} \\
& =\frac{733}{\sqrt{(912)(909)}} \\
& =\frac{733}{\sqrt{829139}} \\
& =\frac{733}{910,571} \\
& =0,850
\end{aligned}
$$

Dari penghitungan sebagaimana tersebut di atas dapat diketahui bahwa hasil analisis data diperoleh $\mathrm{r}$ hitung sebesar 0,850. Langkah selanjutnya adalah menguji 
CENDEKIA, Vol. 9, No. 2, Oktober 2015

p ISSN: 1978 2098; e ISSN: 2407 8557; Web: cendekia.pusatbahasa.or.id Pusat Kajian Bahasa dan Budaya, Surakarta, Indonesia

Zaitun, Siti. 2015. Pengaruh Layanan Bimbingan Penyuluhan terhadap Kenakalan Anak Kelas VI SDN 005 Bontang Utara. Cendekia, 9(2): 195 206.

hipotesis yang dikemukakan. Untuk mengetahui diterima atau ditolaknya hipotesis penelitian, hasil analisis di atas dikonsultasikan dengan $r$ tabel product moment pada taraf signifikansi $\alpha=5 \%$ dengan $\mathrm{N}=63$ yaitu sebesar 0,244 .

Hasil ini menunjukkan bahwa $r$ hitung lebih besar $(>)$ dari $r$ table yang berarti penelitian signifikans. Dengan demikian, hipotesis nol (Ho) ditolak dan hipotesis alternatif (Ha) diterima. Ini artinya hipotesis penelitian yang berbunyi: "Terdapat pengaruh yang signifikan layanan BP terhadap kenakalan anak kelas VI SDN 005 Bontang Utara tahun pelajaran 2005/2006" diterima. Dengan kata lain, layanan BP memiliki pengaruh yang signifikan terhadap kenakalan anak kelas VI SDN 005 Bontang Utara. Hal ini berarti bahwa semakin baik pelaksanaan layanan BP di sekolah, semakin kurang pula kenakalan anak pada siswa.

Berdasarkan data hasil ringkasan skor angket mengenai layanan BP oleh siswa, maka dapatlah diketahui bahwa layanan BP siswa kelas VI SDN 005 Bontang Utara secara umum, termasuk dalam katagori cukup. Hal tersebut ditunjukkan dari skor ratarata jawaban angket mengenai layanan BP terhadap siswa yang diperoleh sebesar 23,2. Skor tersebut berada pada posisi antara 20,8 sampai dengan 25,4 yang berada dalam katagori cukup. Hal ini menunjukkan bahwa pelaksanaan layanan BP terhadap siswa kelas VI SDN 005 Bontang Utara berlangsung cukup baik. Selain itu, berdasarkan hasil persentase terhadap masing-masing katagori layanan BP, sebagian besar siswa yaitu sebanyak $38,1 \%$ atau 24 siswa mendapatkan layanan BP pada katagori cukup. Hal ini mengindikasikan bahwa pelaksanaan layanan BP masih perlu ditingkatkan.

Sedangkan data hasil skor angket mengenai kenakalan anak, maka dapatlah diketahui bahwa secara umum kenakalan anak kelas VI SDN 005 Bontang Utara termasuk dalam katagori cukup. Hal tersebut ditunjukkan dari skor rata-rata angket tentang kenakalan anak yang menghasilkan skor sebesar 25,2. Skor tersebut berada pada interval antara 23 sampai dengan 26 yang berarti dalam katagori cukup.

\section{SIMPULAN}

Berdasarkan hasil analisis data dan pembahasan, dapat diambil kesimpulan penelitian sebagai berikut:

Hasil penelitian mengungkapkan bahwa terdapat pengaruh yang signifikan layanan BP terhadap kenakalan anak kelas VI SDN 005 Bontang Utara tahun pelajaran 2005/2006. Berdasarkan hasil analisis data statistik menggunakan uji korelasi Product Moment, menunjukkan bahwa hasil penghitungan $r$ hitung sebesar 0,850 lebih besar (>) dari $r$ tabel pada taraf signifikansi $\alpha=5 \%$ dengan $N=63$ sebesar 0,244 . Hal ini berarti bahwa hipotesis nol (Ho) ditolak dan hipotesis alternatif (Ha) diterima. Dengan kata lain, jika layanan BP dapat diterapkan dengan baik, tingkat kenakalan anak kelas VI SDN 005 Bontang Utara akan menurun atau berkurang. Sebaliknya, semakin buruk atau kurang baik pelaksanaan layanan BP terhadap siswa, kenakalan anak akan meningkat atau bertambah.

Layanan BP terhadap siswa kelas VI SDN 005 Bontang Utara secara umum, termasuk dalam katagori cukup. Hal tersebut ditunjukkan dari skor rata-rata jawaban angket tentang layanan BP yang diperoleh sebesar 23,2. Skor tersebut berada pada posisi antara 20,8 sampai dengan 25,4 yang mengindikasikan skor layanan BP pada 
CENDEKIA, Vol. 9, No. 2, Oktober 2015

p ISSN: 1978 2098; e ISSN: 2407 8557; Web: cendekia.pusatbahasa.or.id Pusat Kajian Bahasa dan Budaya, Surakarta, Indonesia

Zaitun, Siti. 2015. Pengaruh Layanan Bimbingan Penyuluhan terhadap Kenakalan Anak Kelas VI SDN 005 Bontang Utara. Cendekia, 9(2): 195 206.

katagori cukup. Hal ini menunjukkan bahwa pelaksanaan layanan BP terhadap siswa kelas VI SDN 005 Bontang Utara berlangsung cukup baik.

Sedangkan tingkat kenakalan anak kelas VI SDN 005 Bontang Utara tahun pelajaran 2005/2006 secara umum termasuk dalam kenakalan anak katagori cukup. Hal tersebut ditunjukkan dari skor rata-rata angket tentang kenakalan anak yang menghasilkan skor sebesar 25,2 yang berada pada interval antara 23 sampai dengan 26 dengan katagori cukup. Hal ini menunjukkan bahwa tingkat kenakalan anak pada siswa kelas VI SDN 005 Bontang Utara berlangsung biasa-biasa saja atau sedang. Namun demikian, dari hasil persentase terhadap masing-masing katagori motivasi, diketahui sebagian besar siswa yakni sebanyak 50\% atau sebanyak 31 siswa menunjukkan tingkat kenakalan anak pada katagori kurang.

\section{SARAN}

Dari hasil pembahasan dalam penelitian ini, maka peneliti mencoba memberikan saran-saran sebagai berikut:

Wali Kelas atau guru BP hendaknya dapat memberikan bantuan kepada para siswa yang memerlukan penanganan dalam hal kenakalan anak, baik yang bersifat pengaruh dari luar maupun yang bersifat dari dalam yang khususnya berkaitan dengan pelaksanaan layanan BP, sehingga pada akhirnya siswa akan mampu meningkatkan prestasi belajarnya melalui layanan layanan BP dengan baik dan positif.

Hendaknya kepada pihak sekolah agar dapat melengkapi instrumen pendukung kegiatan dan layanan BP di sekolah sehingga siswa di sekolah dapat memanfaatkan fasilitas tersebut secara positif, dapat membantu perkembangan kepribadian siswa ke arah mandiri, serta dapat meningkatkan motivasi dan prestasi belajar terhadap suatu perkembangan ilmu, wawasan, dan pengetahuannya. Selain itu, fasilitas yang ada juga dapat membantu guru di kelas dalam mengembangkan variasi mengajar yang dapat menumbuhkan minat dan motivasi belajar pada siswa dapat mengurangi kenakalan anak pada siswa termasuk biasa-biasa saja atau sedang. Namun demikian, dari hasil persentase terhadap masing-masing katagori kenakalan anak diketahui sebagian besar siswa, yaitu sebanyak 50\% atau 31 siswa menunjukkan kenakalan anak pada katagori kurang.

\section{DAFTAR PUSTAKA}

Gunarso, Singgih D. 1981. Psikologi Anak. Jakarta: Gunung Mulia. Wirawan, S. Sarwono. 1988. Psikologi Anak. Jakarta: Rajawali Press.

Simanjuntak, B. 1984. Latar Belakang Kenakalan Anak. Bandung: Alumni.

Slameto. 1995. Belajar dan Faktor-faktor yang Mempengaruhinya. Jakarta: Rineka Cipta.

Surya, Moh, dan Rahman Natawidjaya. 1985. Pengantar Bimbingan dan Penyuluhan. Jakarta: Pendidikan dan Kebudayaan Universitas Terbuka.

Walgito, Bimo. 1978. Kenakalan Anak. Yogyakarta: Penerbit FP UGM.

Willis, Sofyan S. 1981. Problema Anak dan Pemecahannya. Bandung: Angkasa.

Winkel, WS. 1981. Bimbingan dan Penyuluhan di Sekolah. Jakarta: PT. Gramedia. 
CENDEKIA, Vol. 9, No. 2, Oktober 2015

p ISSN: 1978 2098; e ISSN: 2407 8557; Web: cendekia.pusatbahasa.or.id Pusat Kajian Bahasa dan Budaya, Surakarta, Indonesia

Zaitun, Siti. 2015. Pengaruh Layanan Bimbingan Penyuluhan terhadap Kenakalan Anak Kelas VI SDN 005 Bontang Utara. Cendekia, 9(2): 195 206.

Basrowi, Muhammad dan Soenyono. 2004. Teori Sosial Dalam Tiga

Paradigma. Surabaya: V de Press

Basrowi, 2005, Memahami Sosiologi, Bogor: Yudistira

Berger, Peter L. dan Thomas Luckmann, 1990. Tafsir Sosial Atas Kenyataan: Risalah tentang Sosiologi Pengetahuan, Terjemahan A. Hasan Basari, Jakarta: LP3ES

Garfinkel, H., 1967, Studies in Ethno Methodology, Englewood Cliffs: Prentice Hall

Munandar, Utami. 2004. Anak-anak Berbakat, Pembinaan dan

Pendidikannya. Jakarta: CV. Rajawali

Majalah Hidayah. 2006. Menelusuri Kehidupan Para Pengemis. Jakarta.:

Dian Rakyat 